\title{
The Quest for the Superior Financial Performance Measures
}

\author{
Mehdi Arabsalehi \\ Department of Accounting, Faculty of Administrative Science and Economics \\ University of Isfahan, Hezarjerib Street, Isfahan, Iran \\ Tel: 98 -91-3328-9157Ｅ-mail: Mehdi_arabsalehi@acnt.ui.ac.ir \\ Iman Mahmoodi \\ Department of Accounting, Faculty of Administrative Science and Economics \\ University of Isfahan, Hezarjerib Street, Isfahan, Iran \\ Tel: 98- 91-7723-6892 E-mail: im_mahmoodi@yahoo.com
}

Received: September 23, 2011

Accepted: October 25, $2011 \quad$ Published: February 1, 2012

doi:10.5539/ijef.v4n2p116

URL: http://dx.doi.org/10.5539/ijef.v4n2p116

\begin{abstract}
This study tries to answer whether value based measures are superior to traditional accounting measures in explaining stock returns. A pooling panel data method on 115 Iranian listed companies in the Tehran Stock Exchange (TSE) from 2001 to 2008 is used to investigate the explanatory power of four value-based measures (including Economic Value Added, Refined Economic Value Added, Market Value Added and Shareholder Value Added) compare to five accounting-based measures (including Earning Per Share, Return On Equity, Return On Assets, Cash Flow from Operations and Return On Sales) in explaining stock returns. Our findings do not provide evidence which support assertions that value-based measures are superior compared with other traditional accounting measures. Relative information content tests revealed that stock returns are more closely associated with ROA and ROE than other performance measures. Furthermore, incremental information content tests suggest that value-based measures add only marginally information content beyond accounting measures. However, the results indicate that accounting measures generally dominate value-based measures.
\end{abstract}

Keywords: Firm performance, Value-based measures, Accounting-based measures, Stock return, Tehran Stock Exchange

\section{Introduction}

After Rappaport's publication of "Creating Shareholder Value" in 1986, it is widely believed that the primary aim of every business entity is to maximize shareholders wealth using efficient allocation of resources (Rappaport, 1998; Worthington and West, 2001, 2004; Maditions et al., 2006, 2009). Therefore, all of the firm activities must be directed to achieve this objective.

Since the 1900s, shareholders to induce managements to adopt a shareholder orientation; lenders to determine the security of their loans; managers to monitor the profitability of the firms and also to make strategic decisions have used traditional accounting-based measures including return on assets (ROA), return on equity (ROE), earning per share (EPS), return on sales (ROS) and cash flow from operations (CFO) (Worthington and West, 2001, 2004).

During the 1980s, the capital markets became more internationalized (Tortella and Brusco, 2003; Maditions et al., 2009) and there was a lot of competition between American and Japanese firms in that time. In addition, it became clear that managers can manipulate accounting earnings to show that their firms have a good performance (Jensen and Murphy, 1990; Tortella and Brusco, 2003). Moreover, investors interested to know all financial information on a firm (Maditions et al., 2009). Therefore, accounting-based measures came under attack and the need for new performance indicators increased.

Since the 1990s, several scholars and consulting firms have suggested new performance measures namely value-based measures, and also argued that these new measures are better than traditional measures for monitoring the real performance of the firms. For example, Shareholder Value Added (SVA) developed by Rappaport and LEK/Alcar Consulting Group (Rappaport, 1986, 1998), Economic Value Added (EVA ${ }^{\circledR}$ ) and Market Value Added 
(MVA) proposed by Stern Stewart \& Co (Stewart, 1991, 1994) and Bacidore et al. (1997) developed Refined Economic Value Added (REVA).

$\mathrm{EVA}^{\circledR}$, which is a trade-marked variant of residual income, considers cost of total employed capital (including debts and equity) for evaluating firm performance. Stewart (1991, p. 66) argues:

"Earnings, earnings per share and earnings growth are misleading measures of corporate performance. The best practical periodic performance measure is $\mathrm{EVA}^{\circledR} . \mathrm{EVA}^{\circledR}$ is the financial performance measure that comes closer than any other to capturing the true economic profit of an enterprise. EVA ${ }^{\circledR}$ also is the performance measure most directly linked to the creation of shareholder wealth over time".

Moreover, Stewart $(1994$, p. 75$)$ states "EVA ${ }^{\circledR}$ is almost $50 \%$ better than its closest accounting-based competitor (including EPS, ROE and ROI) in explaining changes in shareholder wealth". In addition, other sources strongly supported the EVA ${ }^{\circledR}$. Fortune, for example, called it "Today's hottest financial idea", "The Real Key to Creating Wealth" (30 September, 1993) and "A New Way to Find Bargains" (9 December, 1996) (Worthington and West, 2001, 2004; Biddle et al. 1997). These promotions of EVA ${ }^{\circledR}$ have led to widespread adoption of EVA ${ }^{\circledR}$ initially in the USA by several international companies, including AT\&T, Coca Cola, DuPont, Eli Lilly, Polaroid, Quaker Oats, Sprint, Teledyne, Tenneco and Whirlpool and later in the other countries, like Australia, the UK, Canada, France, Germany, Japan and Turkey (Worthington and West, 2001, 2004; Biddle et al. 1997).

Despite all the widespread support for the EVA ${ }^{\circledR}$, and the claim that value-based measures are superior to traditional accounting-based measures, several empirical studies (e.g. Biddle et al, 1997; Zimmerman, 1997; Turvey et al, 2000; Chen and Dodd, 2001; Worthington and West, 2001; Copeland, 2002; Sparling and Turvey, 2003; Ismail, 2006; Maditions et al, 2006, 2009 and Lee and Kim, 2009) indicate either poor or no significant association between $\mathrm{EVA}^{\circledR}$ and stock return or market value. However, the reported results are mixed and our inquiry is motivated by these results.

The purpose of this paper is to examine the explanatory power of four value-based measures (including SVA, EVA ${ }^{\circledR}$, REVA and MVA) compare to five traditional accounting measures (including EPS, ROA, ROE, CFO and ROS) in explaining stock return in Iranian capital market, as an emerging market. In this study, both relative and incremental information content approaches and also a pooling panel data procedure on 115 listed firms in the Tehran Stock Exchange are employed. However, the results indicate that traditional measures are superior to value-based measures in explaining stock returns and also reveal that value-based measures add only slightly information content beyond accounting measures.

The rest of this paper is structured as follows: the following section presents literature review. The next section describes variables and methodology of the research. The next to last section presents empirical findings. Finally, the results are summarized and discussed in the last section.

\section{Literature Review}

The literature on $\mathrm{EVA}^{\circledR}$ does not provide conclusive evidence. Although some studies (e.g. Stewart, 1991, 1994; Stern et al., 1995; O'Byrne, 1996; Bao and Bao, 1998; Uyemura et al. 1996; Lehn and Makhija, 1997; Forker and Powell, 2004; Worthington and West, 2004) revealed that EVA ${ }^{\circledR}$ is more associated with stock return and market value than accounting measures, but several studies (e.g. Biddle et al. 1997; Turvey et al., 2000; Chen and Dodd, 2001; Worthington and West, 2001; Copeland, 2002; Palliam, 2006; Maditions et al., 2006, 2009) found opposite results and questioned the efficiency of $\mathrm{EVA}^{\circledR}$.

Stewart (1991) suggested that there is a strong relation between the averaged standardized values of EVA ${ }^{\circledR}$ and MVA. Lehn and Makhija (1997) found that $\mathrm{EVA}^{\circledR}$ and MVA are more associated with stock return than accounting indicators, such as ROA, ROE and ROS. O’Byrne (1996) concluded that EVA ${ }^{\circledR}$ outperforms earnings in explaining firm values. Milunovich and Tseui (1996) and Uyemura et al. (1996) indicated the similar results. Bao and Bao (1998) examined the usefulness of value added and abnormal economic earnings and found that the explanatory power of value added is higher than that of earnings. Worthington and West (2004) investigated the relative information content of $\mathrm{EVA}^{\mathbb{B}}$ and other commonly-used accounting-based measures, including earnings, net cash flow and residual income, of 110 Australian companies over the period 1992-1998. They revealed that returns are more closely associated with $\mathrm{EVA}^{\circledR}$ than residual income, earnings and net cash flow, respectively. Dastgir and Izadinia (2004) indicated that there are significant correlations between $\mathrm{EVA}^{\circledR}$, market value and market value added measures.

On the other hand, there are several empirical studies that used the same methodology but found opposite results. Biddle et al. (1997) examined the relative and incremental information content of EVA ${ }^{\circledR}$, RI, CFO and accounting earnings of 773 firms over the period 1984-1993 (6174 firm-year observations) and found accounting earnings 
outperform other indicators. They suggested EVA ${ }^{\circledR}$ adds only marginally to information content beyond earnings. Kramer and Pushner (1997) found the explanatory power of NOPAT is higher than that of EVA ${ }^{\circledR}$ in the explaining MVA. Bacidore et al. (1997) developed REVA and examined the explanatory power of REVA and EVA ${ }^{\circledR}$ in explaining abnormal returns and their ability to predict shareholder value creation. They revealed that REVA statistically outperforms EVA ${ }^{\circledR}$.

Ismail (2006) revealed that NOPAT and net income outperform EVA ${ }^{\circledR}$ and residual income in explaining stock return and also found that accruals and operating cash flow have significant incremental information content, while the accounting adjustments of $\mathrm{EVA}^{\circledR}$ proponents have significantly less contribution in explaining stock return. Palliam (2006) concluded $\mathrm{EVA}^{\circledR}$ is somewhat invalid, unreliable, and questionable. Moreover, similar results were reported by Chen and Dodd (1997, 2001), Kim (2006), Maditions et al. (2006), Kyriazis and Anastasis (2007) and Lee and Kim (2009).

Maditions et al. (2009) investigated the explanatory power of EVA ${ }^{\circledR}$ and SVA compare with EPS, ROE and ROI in explaining stock returns in the Athens Stock Exchange over the period 1992-2001. They found that stock returns are more closely associated with EPS than EVA $^{\circledR}$ and other measures. Moreover they suggested that the pairwise combination of $\mathrm{EVA}^{\circledR}$ with EPS increases significantly the explanatory power of EPS in explaining stock market returns. Arabsalehi and Mahmoodi (2011) conclude that accounting measures have more explanatory power than EVA $^{\circledR}$ in explaining stock return in the TSE.

However, the results of the empirical studies on the value relevance of traditional accounting and value-based performance measures are mixed. In addition, evidence exists that emerging market stock returns are influenced by different factors than those that influence the stock returns in developed capital markets (Harvey, 1995; Bhattacharya et al., 2001). Therefore, it seems it is very important to provide more evidence for the literature by conducting a comprehensive study, for the first time in the Tehran Stock Exchange as an emerging market with specific features, which employs four value-based measures $\left(\mathrm{EVA}^{\circledR}\right.$, REVA, SVA and MVA) and five accounting-based measures (EPS, ROE, ROA, ROS and CFO) and also uses both a relative and incremental information content approaches.

\section{Sample, Variables and Methodology}

\subsection{Sample}

In this study, a sample of listed firms in the Tehran Stock Exchange (TSE) over the years from 2001 to 2008 is used. The firms with long periods without transactions (more than three months) are omitted. Moreover, since all the financial companies and banks operate in a different way, they are excluded from the sample. Furthermore, the sample is reduced because of the lack of some company data. Finally, a sample consisting of 115 Iranian firms during 2001-2008 is selected.

\subsection{Definition and Measurement of the Variables}

In this study, the dependent variable is the annual stock return which is directly obtained from an Iranian Database, namely Rahavard Novin. The independent variables are EPS, ROE, ROA, ROS, CFO, EVA ${ }^{\circledR}$, REVA, SVA and MVA.

EPS shows how much profit is created on per share over a period and is calculated by dividing net income by the average number of common shares outstanding. ROE is a profitability ratio that focuses on the return on the shareholders' equity and is calculated by dividing net income by average equity. ROA is another profitability ratio that presents the return on all of the firm's assets and is calculated by dividing net income plus interest expenses by average total assets. ROS is measured by dividing operating income by total sales. CFO shows net cash provided by operating activities and, in this study, is gotten from the statement of cash flows.

$\mathrm{EVA}^{\circledR}$ is defined as the profit of a firm from operating activities after consideration of the cost of all invested capital. In the other words, $\mathrm{EVA}^{\circledR}$ is computed as follows:

$$
\mathrm{EVA}_{\mathrm{t}}=\mathrm{NOPAT}_{\mathrm{t}}-\left(\mathrm{WACC}_{\mathrm{t}} \times \mathrm{IC}_{\mathrm{t}-1}\right)
$$

Where; NOPAT is net operating profit after tax in year t. IC is the total invested capital in year $t-1$, WACC is weighted average cost of capital in year $t$.

In this study, $\mathrm{EVA}^{\circledR}$ is calculated by adopting the Stern Stewart's approach. Therefore, firstly NOPAT, then IC and finally, WACC are calculated. Moreover, to calculate NOPAT and IC a series of adjustments is needed. These accounting adjustments are considered to shift the book value closer to their economic values.

However, NOPAT is calculated by subtracting tax from earnings before interest and tax (EBIT). Invested Capital (IC) is computed by adding the book value of equity and all of the interest-bearing short and long term liabilities. 
The accounting adjustment figures to NOPAT and IC are manually gotten from accompanying notes. In this paper, the adjustments to IC include: adding certain marketing costs, R\&D and training expenses; adding allowance for bad debts and inventory obsolescence; adding employee retirement, investment and accrued expense reserves. Moreover, to consider adjustments to NOPAT, changes of these items over one year are added to NOPAT.

The cost of capital (WACC) is calculated as follows:

$$
\text { WACC }=\left[\left(\frac{D}{E+D}\right) \times K_{d} \times(1-T)\right]+\left[\left(\frac{E}{E+D}\right) \times K_{e}\right]
$$

Where; $\mathrm{D}$ is the book value of debts, $\mathrm{E}$ is the market value of equity, $\mathrm{K}_{\mathrm{d}}$ is the cost of debts, $\mathrm{T}$ is the rate of tax and $\mathrm{K}_{\mathrm{e}}$ is the cost of equity.

In this study, The Capital Assets Pricing Model (CAPM) is employed to estimate the cost of equity $\left(\mathrm{K}_{\mathrm{e}}\right)$. The CAPM assumes that higher expected returns require taking higher risks (Fama and French, 1992, 1993). However, to estimate the cost of equity for every firm in each year, firstly using 36-monthly returns of each stock $\left(\mathrm{R}_{\mathrm{i}}\right)$ and 36-monthly returns of market $\left(R_{m}\right)$ the annual systematic risk $(\beta)$ is estimated for each stock in every year using following equation:

$$
\beta_{\mathrm{i}}=\frac{\operatorname{Cov}\left(\mathrm{R}_{\mathrm{i}}, \mathrm{R}_{\mathrm{m}}\right)}{\operatorname{Var}\left(\mathrm{R}_{\mathrm{m}}\right)}
$$

Then, the three-month rate of government bonds, which is acquired directly from the website of the Central Bank of Iran (Note 1), is considered as risk free interest rate $\left(\mathrm{R}_{\mathrm{f}}\right)$. Finally, the cost of equity $\left(\mathrm{K}_{\mathrm{e}}\right)$ is estimated for each firm in year $t$ using the following equation:

Bacidore et al. (1997, p. 15) state:

$$
\mathrm{K}_{\mathrm{e}}=\mathrm{R}_{\mathrm{f}}+\left(\mathrm{R}_{\mathrm{m}}-\mathrm{R}_{\mathrm{f}}\right) \beta_{\mathrm{i}}
$$

The key distinction between EVA ${ }^{\circledR}$ and REVA is that REVA assesses its capital charge for period $t$ on the market value of the firm at the end of period $t-1$ (or beginning of period $t$ ) rather than on the economic book value of the assets in place.

Therefore, following Bacidore et al. (1997), REVA is calculated as follows:

$$
\mathrm{REVA}_{\mathrm{t}}=\mathrm{NOPAT}_{\mathrm{t}}-\left(\mathrm{WACC}_{\mathrm{t}} \times \mathrm{MV}_{\mathrm{t}-1}\right)
$$

Where; REVA is refined EVA ${ }^{\circledR}$, NOPAT is the net operating profit after tax and MV is the market value of total invested capital which is calculated by adding the market value of equity and the book value of total interest-bearing liabilities.

SVA presents the change in shareholder's wealth over a period (Rappaport, 1986, 1998). Following Rappaport (1986, 1998), SVA is calculated as follows:

$$
\mathrm{SVA}=\frac{\Delta \mathrm{NOPAT}_{\mathrm{t}}}{\mathrm{K} \times(\mathrm{K}+1)^{\mathrm{t}-1}}-\mathrm{PV} \Delta \mathrm{Inv}
$$

Where; $\triangle$ NOPAT is the changes in NOPAT, $\mathrm{K}$ is the cost of capital (WACC) and PVD Inv is the present value of total annual changes in investments.

Finally, MVA is the difference between the market value of firm and its book value. Since the debt is estimated according to the book value, therefore in this study, the MVA is computed as the market value of equity minus the book value of equity.

\subsection{The Model}

This study investigates the superiority of value-based measures over the traditional measures in explaining of stock returns using pooling panel data procedure. A pooling method, in general terms, is as following:

$$
Y_{i t}=\alpha_{i t}+\beta X_{i t}+\varepsilon_{i t} \quad i=1, \ldots, N ; t=1, \ldots, T
$$

Where; $\mathrm{Y}_{\mathrm{it}}$ is the dependent variable (annual stock return) of firm $\mathrm{i}$ in year t. $a$ is the intercept of model and $\mathrm{X}_{\mathrm{it}}$ represents the performance measures (e.g. EVA ${ }^{\circledR}$, REVA, SVA, MVA, EPS, ROA, ROE, ROS and CFO) of firm i in year $t$. In this study, all of the financial performance measures except for ROA, ROE and ROS are divided by market value of equity in year $\mathrm{t}-1$.

There are different methods of pooling panel data (including pooled models, fixed effect models and random effect models) therefore an F-test and Hausman test are employed to distinguish the best model from pooling models 
(Baltagi, 2005). In this study, both relative and incremental information content approaches are used. Since there are nine performance measures, thus, nine models are conducted to assess the relative information content. Moreover, twenty models are developed using pairwise combinations of one value-based measure and one traditional measure.

Furthermore, in this study, the stationary of all variables is tested using a panel unit root test, namely Levin, Lin and Chu test (2002). Levin, Lin and Chu (LLC) test assumes that there is a common unit root process across cross-sections and employs a null hypothesis of a unit root against the alternative that each variable is stationary. Heteroskedasticity is also tested using both Levene (1960) and Brown-Forsythe tests (1974).

\section{Empirical results}

\subsection{Descriptive Statistics}

Table I shows the descriptive statistics of all variables. The first interesting finding is that all variables, except for MVA, have a positive mean. Mean statistics indicate that CFO (1.252) has the largest and EPS (4.95E-09) has the lowest mean among the other variables. Furthermore, descriptive statistics reveal that SVA (38.05), MVA (22.09) have the highest, EPS (9.79E-09) and ROA (0.136) have the lowest standard deviation compare to the other variables. The LLC tests suggest that all variables are stationary.

\subsection{Relative Information Content Tests}

Table II presents the results of the relative information content tests for each performance measure. The first step in the analysis is to select the most appropriate pooling panel data techniques. In order to distinguish the preferable set of results statistically, the F-tests and Hausman tests are employed. Firstly, the models are estimated by pooled model, and tested against the fixed and random effects models using an F-test. Then, Hausman tests are used to choose between a fixed or random effects model.

However, the F-tests are not statistically significant for all models which indicate the preference of the pooled models over the fixed and random effects models. Therefore, the results of pooled models are used to assess the relative information content of performance measure.

Table II shows that there are statistical relationships between two value-based measures, including EVA ${ }^{\circledR}$ and MVA, and stock returns at 10 percent level while the association between REVA and stock return is significant at 5 percent level. Moreover, there is no significant relation between SVA and stock return. The results reveal that the associations between stock returns and all accounting-based measures, except for $\mathrm{CFO}$, are significant at 1-percent level.

The results indicate that ROA $\left(\mathrm{R}^{2}=24.89\right.$ percent $)$ and $\mathrm{ROE}\left(\mathrm{R}^{2}=14.15\right.$ percent $)$ provide more information in explaining stock returns than other performance measures respectively. These findings are consistent with Chen and Dodd (1997) who revealed that ROA $\left(\mathrm{R}^{2}=25 \%\right)$ have the strongest correlation with stock returns. REVA $\left(\mathrm{R}^{2}=3.70\right.$ percent) have the highest explanatory power among value-based measures which is consistent with Bacidore et al. (1997) who suggest REVA dominates EVA ${ }^{\circledR}$.

However, our findings reveal that ROA, as an accounting-based measure, is more closely associated with stock returns than other measures. In the other words, relative information content tests indicate that traditional accounting measures provide more information in explaining stock returns than value-based measures, especially $\mathrm{EVA}^{\circledR}$. These results are consistent with Biddle et al. (1997), Worthington and West (2001), Chen and Dodd (1997, 2001), Ismail (2006) and Maditions et al. $(2006,2009)$ who indicate traditional measures dominate value-based measures.

\subsection{Incremental Information Content Tests}

The incremental information content approach tries to answer whether combination of one value-based measure and one accounting measure can increase the explanatory power in explaining stock return. Since this study employs five traditional measures and also four value-based measure, therefore, twenty separate regressions are developed from pairwise combinations of each traditional accounting measure (EPS, ROA, ROE, ROS and CFO) with each of the value-based measure (EVA ${ }^{\circledR}, \mathrm{SVA}, \mathrm{REVA}$ and MVA). The following equations ( 1 to 5 ) have been employed to test the incremental information content of the $\mathrm{EVA}^{\circledR}$ :

$$
\begin{gathered}
\mathrm{R}_{\mathrm{it}}=\alpha+\mathrm{a}_{1} \mathrm{EPS}_{\mathrm{it}} / \mathrm{MV}_{\mathrm{it}-1}+\mathrm{a}_{2} \mathrm{EVA}_{\mathrm{it}} / \mathrm{MV}_{\mathrm{it}-1}+\varepsilon_{\mathrm{it}} \\
\mathrm{R}_{\mathrm{it}}=\alpha+\mathrm{b}_{1} \mathrm{ROA}_{\mathrm{it}}+\mathrm{b}_{2} \mathrm{EVA}_{\mathrm{it}} / \mathrm{MV}_{\mathrm{it}-1}+\varepsilon_{\mathrm{it}} \\
\mathrm{R}_{\mathrm{it}}=\alpha+\mathrm{c}_{1} \mathrm{ROE}_{\mathrm{it}}+\mathrm{c}_{2} \mathrm{EVA}_{\mathrm{it}} / \mathrm{MV}_{\mathrm{it}-1}+\varepsilon_{\mathrm{it}} \\
\mathrm{R}_{\mathrm{it}}=\alpha+\mathrm{d}_{1} \mathrm{ROS}_{\mathrm{it}}+\mathrm{d}_{2} \mathrm{EVA}_{\mathrm{it}} / \mathrm{MV}_{\mathrm{it}-1}+\varepsilon_{\mathrm{it}} \\
\mathrm{R}_{\mathrm{it}}=\alpha+\mathrm{e}_{1} \mathrm{CFO}_{\mathrm{it}} / \mathrm{MV}_{\mathrm{it}-1}+\mathrm{e}_{2} \mathrm{EVA}_{\mathrm{it}} / \mathrm{MV}_{\mathrm{it}-1}+\varepsilon_{\mathrm{it}}
\end{gathered}
$$


Table III shows the results of incremental information content test of the EVA ${ }^{\circledR}$. The results of F-test indicate that pooled models are appropriate to use. Incremental information tests of $\mathrm{EVA}^{\circledR}$ show that all regressions, except for regression 5, are statistically significant at 1 percent level. The highest $R^{2}(26.61)$ is reported in the model 2 which $\mathrm{EVA}^{\circledR}$ is combined with ROA. In the other words, by combining EVA ${ }^{\circledR}$ and ROA the explanatory power of ROA increases from 24.89 percent to 26.61 percent. In addition, the combinations of $\mathrm{EVA}^{\circledR}$ with EPS, $\mathrm{EVA}^{\circledR}$ with ROE and EVA ${ }^{\circledR}$ with ROS increase the $\mathrm{R}^{2}$ of EPS, ROE and ROS from 7.26, 14.15 and 5.40 to $7.895,14.92$ and 6.61 percent respectively. Therefore, $\mathrm{EVA}^{\circledR}$ adds only slightly to information content beyond accounting-based measures. These findings are consistent with Biddle et al. (1997) who indicate the same results.

Table IV shows the results of the incremental information content tests of REVA. The results of F-tests notice that it is better to use pooled models to estimate the following equations:

$$
\begin{aligned}
& \mathrm{R}_{\text {it }}=\alpha+\mathrm{a}_{1} \mathrm{EPS}_{\mathrm{it}} / \mathrm{MV}_{\mathrm{it}-1}+\mathrm{a}_{2} \mathrm{REVA}_{\mathrm{it}} / \mathrm{MV}_{\mathrm{it}-1}+\varepsilon_{\mathrm{it}} \\
& \mathrm{R}_{\mathrm{it}}=\alpha+\mathrm{b}_{1} \mathrm{ROA}_{\mathrm{it}}+\mathrm{b}_{2} \mathrm{REVA}_{\mathrm{it}} / \mathrm{MV}_{\mathrm{it}-1}+\varepsilon_{\mathrm{it}} \\
& \mathrm{R}_{\mathrm{it}}=\alpha+\mathrm{c}_{1} \mathrm{ROE}_{\mathrm{it}}+\mathrm{c}_{2} \mathrm{REVA}_{\mathrm{it}} / \mathrm{MV}_{\mathrm{it}-1}+\varepsilon_{\mathrm{it}} \\
& \mathrm{R}_{\mathrm{it}}=\alpha+\mathrm{d}_{1} \mathrm{ROS}_{\mathrm{it}}+\mathrm{d}_{2} \mathrm{REVA}_{\mathrm{it}} / \mathrm{MV}_{\mathrm{it}-1}+\varepsilon_{\mathrm{it}} \\
& \mathrm{R}_{\mathrm{it}}=\alpha+\mathrm{e}_{1} \mathrm{CFO}_{\mathrm{it}} / \mathrm{MV}_{\mathrm{it}-1}+\mathrm{e}_{2} \mathrm{REVA}_{\mathrm{it}} / \mathrm{MV}_{\mathrm{it}-1}+\varepsilon_{\mathrm{it}}
\end{aligned}
$$

Our findings indicate that regressions 6 to 9 are significant at 1 percent level while regression 10 is significant at 5 percent level, and also the combination of REVA and ROA (regression 7) has the highest explanatory power in explaining stock returns. In comparison to incremental information content of $\mathrm{EVA}^{\circledR}$, the main point is that the results of the pairwise combinations of REVA with one traditional measure (EPS, ROA, ROE, ROS and CFO) provide more information content. These results are consistent with Bacidore et al. (1997) who suggest REVA outperforms EVA ${ }^{\circledR}$.

Furthermore, the following models are employed to test the incremental information of MVA:

$$
\begin{aligned}
& \mathrm{R}_{\mathrm{it}}=\alpha+\mathrm{a}_{1} \mathrm{EPS}_{\mathrm{it}} / \mathrm{MV}_{\mathrm{it}-1}+\mathrm{a}_{2} \mathrm{MVA}_{\mathrm{it}} / \mathrm{MV}_{\mathrm{it}-1}+\varepsilon_{\mathrm{it}} \\
& \mathrm{R}_{\mathrm{it}}=\alpha+\mathrm{b}_{1} \mathrm{ROA}_{\mathrm{it}}+\mathrm{b}_{2} \mathrm{MVA}_{\mathrm{it}} / \mathrm{MV}_{\mathrm{it}-1}+\varepsilon_{\mathrm{it}} \\
& \mathrm{R}_{\mathrm{it}}=\alpha+\mathrm{c}_{1} \mathrm{ROE}_{\mathrm{it}}+\mathrm{c}_{2} \mathrm{MVA}_{\mathrm{it}} / \mathrm{MV}_{\mathrm{it}-1}+\varepsilon_{\mathrm{it}} \\
& \mathrm{R}_{\mathrm{it}}=\alpha+\mathrm{d}_{1} \mathrm{ROS}_{\mathrm{it}}+\mathrm{d}_{2} \mathrm{MVA}_{\mathrm{it}} / \mathrm{MV}_{\mathrm{it}-1}+\varepsilon_{\mathrm{it}} \\
& \mathrm{R}_{\text {it }}=\alpha+\mathrm{e}_{1} \mathrm{CFO}_{\text {it }} / \mathrm{MV}_{\text {it- }-1}+\mathrm{e}_{2} \mathrm{MVA}_{\text {it }} / \mathrm{MV}_{\text {it- }-1}+\varepsilon_{\text {it }}
\end{aligned}
$$

Table $\mathrm{V}$ presents the results of the incremental information of MVA. The results of F-tests suggest that pooled models should be used. As shown in the Table V, models 11 to 14 are significant at 1-percent level while the model 15 is insignificant. In addition, model 12 reports the highest correlation $\left(\mathrm{R}^{2}=25.16\right.$ percent $)$ which combines MVA with ROA. Generally, by considering the results of the relative information content of accounting measures, MVA adds only slightly to information content beyond those measures.

Finally, the incremental information content of SVA is examined using five following models:

$$
\begin{aligned}
& \mathrm{R}_{\mathrm{it}}=\alpha+\mathrm{a}_{1} \mathrm{EPS}_{\mathrm{it}} / \mathrm{MV}_{\mathrm{it}-1}+\mathrm{a}_{2} \mathrm{SVA}_{\mathrm{it}} / \mathrm{MV}_{\mathrm{it}-1}+\varepsilon_{\mathrm{it}} \\
& \mathrm{R}_{\mathrm{it}}=\alpha+\mathrm{b}_{1} \mathrm{ROA}_{\mathrm{it}}+\mathrm{b}_{2} \mathrm{SVA}_{\mathrm{it}} / \mathrm{MV}_{\mathrm{it}-1}+\varepsilon_{\mathrm{it}} \\
& \mathrm{R}_{\mathrm{it}}=\alpha+\mathrm{c}_{1} \mathrm{ROE}_{\mathrm{it}}+\mathrm{c}_{2} \mathrm{SVA}_{\mathrm{it}} / \mathrm{MV}_{\mathrm{it}-1}+\varepsilon_{\mathrm{it}} \\
& \mathrm{R}_{\text {it }}=\alpha+\mathrm{d}_{1} \mathrm{ROS}_{\mathrm{it}}+\mathrm{d}_{2} \mathrm{SVA}_{\mathrm{it}} / \mathrm{MV}_{\mathrm{it}-1}+\varepsilon_{\mathrm{it}} \\
& \mathrm{R}_{\mathrm{it}}=\alpha+\mathrm{e}_{1} \mathrm{CFO}_{\mathrm{it}} / \mathrm{MV}_{\mathrm{it}-1}+\mathrm{e}_{2} \mathrm{SVA}_{\mathrm{it}} / \mathrm{MV}_{\mathrm{it}-1}+\varepsilon_{\mathrm{it}}
\end{aligned}
$$


Table VI indicates the results of incremental information content of SVA. The results of F-tests show the preference of the pooled model over fixed and random effects model. All regression models, except for model 20, are statistically significant at 1-percent level.

By adding SVA to EPS, ROE and ROS the explanatory power increases from 7.26, 14.15 and 5.40 to $7.41,14.25$ and 5.44 percent respectively while the combination of SVA with ROA decreases the $\mathrm{R}^{2}$ of ROA from 24.89 to 24.78 percent. Our findings suggest that SVA has low incremental information content which these findings are largely consistent with Maditions et al. (2009) who report the similar results.

\section{Summary and Conclusions}

In this study, pooling panel data methods and also both relative and incremental information content approaches were employed to investigate whether it is better to use value-based measures (including EVA ${ }^{\circledR}$, REVA, MVA and SVA) than traditional accounting measures (including EPS, ROA, ROE, ROS and CFO).

The relative information content tests revealed that ROA $\left(\mathrm{R}^{2}=24.89\right.$ percent $)$ is more closely associated with stock return. These results are more consistent with Chen and Dodd (1997) who show that ROA provides more information than other measures. In addition, it was noticed that REVA has the highest explanatory power among value-based measures, which is consistent with Bacidore et al. (1997) who suggest REVA outperforms EVA ${ }^{\circledR}$. The relative information content test, in general terms, does not support assertions that value-based measures are superior to traditional indicators which are consistent with Biddle et al. (1997), Worthington and West (2001), Chen and Dodd (1997, 2001), Maditions et al. (2006, 2009), Ismail (2006), Palliam (2006), Kyriazis and Anastasis (2007) and Lee and Kim (2009).

The incremental information content tests indicated interesting results. First, the pariwise combination of REVA with ROA increases the explanatory power of ROA in explaining stock returns from 24.89 to 32.42 percent. Second, REVA outperforms other value-based measures in this regard. Finally, in sum, value-based measures add only slightly to information content beyond accounting measures which are consistent with Biddle et al. (1997) who revealed similar results.

There are at least three ways in which this study can be further extended. First, in this paper we used the CAPM to estimate the cost of capital, so it might be a good idea to use another approaches, such as Arbitrage Pricing Theory (APT) or Gordon Growth Model. Second, this study can be done in the developed capital markets and investigates whether the results are maintained. Finally, in this paper stock returns are used as dependent variable, other variables such as MVA or Tobin's Q could be used.

\section{References}

Arabsalehi, M., \& Mahmoodi, I. (2011). EVA ${ }^{\circledR}$ or Traditional Accounting Measures, Empirical Evidence from Iran. International Research Journal of Finance and Economics, Issue 65, pp. 51-58.

Bacidore., J., Boquist, J., Milbourn, T., \& Thakor, A. (1997). The search for the best financial performance measure. Financial Analyst Journal, May/June, pp. 11-20. http://dx.doi.org/10.2469/faj.v53.n3.2081

Baltagi, B. H. (2005). Econometric Analysis of Panel Data, (third Edition), New York, NY: John Wiley \& Sons Inc.

Bao, B. H., \& Bao, D. H. (1998). Usefulness of value added and abnormal economic earnings: an empirical examination. Journal of Business Finance and Accounting, Vol. 25, No. 1-2, pp. 251-65. http://dx.doi.org/10.1111/1468-5957.00186

Bhattacharya, U., Daouk, H., Jorgenson, B., \& Kehr, C. H. (2000). When an event is not an event: the curious case of an emerging market. Journal of Financial Economics, Vol. 55, pp. 69-101. http://dx.doi.org/10.1016/S0304-405X(99)00045-8

Biddle, G. C., Bowen, R. M., \& Wallace, J.S. (1997). Dose EVA beat earning? Evidence on associations with stock returns and firm values. Journal of Accounting and Economics, Vol. 25, No. 3, pp. 301-36.

Chen, S., \& Dodd, J. L. (1997). Economic value added: an empirical examination of a new corporate performance measure. Journal of Managerial Issues, Vol. 9, No. 3, pp. 318-33.

Chen, S., \& Dodd, J. L. (2001). Operating income, residual income and EVA: Which metric is more value relevant? Journal of Managerial Issues, Vol. 13, No. 1, pp. 65-86.

Copeland, T. (2002). What do practitioners want?,Journal of Applied Finance, Vol. 12, No. 1, pp. 5-12.

Dastgir, M, \& Izadinia, N. (2004). The Relationship between Internal and Measures of Value Creation and External Measures of Operation Evaluation. Iranian Accounting Studies, vol. 5, pp.131-155. 
Fama E. F., \& French K. R. (1992). The cross-section of expected stock returns. The Journal of Finance, Vol. 47, pp. 427-65. http://dx.doi.org/10.2307/2329112

Fama E. F., \& French K. R. (1993).. Common risk factors in the returns on stocks and bonds. The Journal of Finance, Vol. 33, pp. 3-56. http://dx.doi.org/10.1016/0304-405X(93)90023-5

Forker, J., \& Powell, R. (2004). Does EVA beat earnings? Evidence on associations with stock returns and firm values - revisited, paper presented at EAAMeeting, Prague,1-3 April 2004.

Harvey, C. R. (1995). Predictable risk and returns in emerging markets. The Review of Financial Studies, Vol. 8, pp. 773-816. http://dx.doi.org/10.1093/rfs/8.3.773

Ismail, A. (2006). Is economic value added more associated with stock return than accounting earnings? The UK evidence. International Journal of Managerial Finance, Vol. 2, No. 4, pp. 343-353. http://dx.doi.org/10.1108/17439130610705526

Jensen, M. C., \& Murphy, K. J. (1990). CEO Incentives - it's not how much you pay but how. Harvard Business Review, Vol. 68, pp. 138-149.

Kim, W.G. (2006). EVA and traditional accounting measures: which metric is a better predictor of market value of hospitality companies? Journal of Hospitality \& Tourism Research, Vol. 30, No. 1, pp. 34-49. http://dx.doi.org/10.1177/1096348005284268

Kramer, J. K., \& Pushner, G. (1997). An empirical analysis of economic value added as a proxy for market value added. Financial Practice and Education, Vol. 7, No. 1, pp. 41-49.

Kyriazis, D., \& Anastasis, C. (2007). The validity of the economic value added approach: an empirical application. European Financial Management, Vol. 13, No. 1, pp. 71-100. http://dx.doi.org/10.1111/j.1468-036X.2006.00286.x

Lee, S., \& Kim, W. G. (2009). EVA, refined EVA, MVA, or traditional performance measures for the hospitality industry? International Journal of Hospitality Management, Vol. 28, pp. 439-445. http://dx.doi.org/10.1016/j.ijhm.2009.01.004

Lehn, K., \& Makhija, A. K. (1997). EVA, Accounting Profits, and CEO Turnover: An Empirical Examination, 1985-1994. Journal of Applied Corporate Finance, Vol. 10, No. 2, pp. 90-97. http://dx.doi.org/10.1111/j.1745-6622.1997.tb00139.x

Levene, H. (1960). Robust Tests for Equality of Variances, in Contributions to Probability and Statistics (first edition), Olkin, Palo Alto, CA: Stanford Univ. Press.

Levin, A., Lin, C.F., \& Chu, C.J. (2002). Unit root tests in panel data: Asymptotic and finite-sample properties. Journal of Econometrics, Vol. 108, pp. 1-24. http://dx.doi.org/10.1016/S0304-4076(01)00098-7

Maditions, I. D., Sevic, Z., \& Theriou, N. G. (2006). The Introduction of Economic Value Added in the Greek Corporate Sector. The Southeuropean Review of Business \& Accounting, Vol. 4, No. 2, pp. 1-11.

Maditions, I. D., Sevic, Z., \& Theriou, N.G. (2009). Modeling traditional accounting and modern value-based performance measures to explain stock market returns in the Athens Stock Exchange (ASE). Journal of Modelling in Management, Vol. 4, No. 3, pp. 182-201. http://dx.doi.org/10.1108/17465660911006431

Milunovich, S., \& Tsuei., A. (1996). EVA in the computer industry. Journal of Applied Corporate Finance, Vol. 9 , No. 2, pp. 104-15.

O’Byrne, S. F. (1996). EVA and market value. Journal of Applied Corporate Finance, Vol. 9, No. 1, pp. 116-25.

Palliam, R. (2006). Further evidence on the information content of economic value added. Review of Accounting and Finance, Vol. 5, No. 3, pp. 204-215. http://dx.doi.org/ 10.1108/14757700610686417

Rappaport, A. (1986). Creating Shareholder Value: A Guide for Managers and Investors (first edition), New York, NY: The Free Press.

Rappaport, A. (1998). Creating Shareholder Value: A Guide for Managers and Investors (second edition), New York, NY: The Free Press.

Sparling, D., \& Turvey, C. G. (2003). Further thoughts on the relationship between economic value added and stock market performance. Agribusiness, Vol. 19, No. 2, pp. 255-67. http://dx.doi.org/10.1002/agr.10054

Stern, J. M., Stewart, G. B., \& Chew, D. H. (1995). The EVA financial system. Journal of Applied Corporate Finance, Vol. 8, No. 2, pp. 32-46. 
Stewart, G. B. (1991). The Quest for Value: A Guide for Senior Managers, New York, NY: HarperCollins, Publishers Inc.

Stewart, G. B. (1994). EVA: fact or fantasy. Journal of Applied Corporate Finance, Vol. 7, No. 2, pp. 71-84.

Tortella, B., \& Brusco, S. (2003). THE ECONOMIC VALUE ADDED (EVA): AN ANALYSIS OF MARKET REACTION. Advances in Accounting, Vol. 20, pp. 265-290. http://dx.doi.org/10.1016/S0882-6110(03)20012-2

Turvey, C. G., Lake, L., Van Duren, E., \& Sparing, D. (2000). The relationship between economic value added and the stock market performance of agribusiness firms. Agribusiness, Vol. 16, No. 4, pp. 399-416. http://dx.doi.org/10.1002/1520-6297(200023)16:4<399::AID-AGR2>3.3.CO;2-0

Uyemura, D. G., Kantor, C. C., \& Petit, J. M. (1996). EVA for banks: value creation, risk management and profitability measurement. Journal of Applied Corporate Finance, Vol. 9 No. 2, pp. 94-111.

Worthington, A. C., \& West T. (2001). Economic Value-Added: A Review of the Theoretical and Empirical Literature., Asian Review of Accounting, Vol. 9, No. 1, pp. 67-86. http://dx.doi.org/10.1108/eb060736

Worthington, A. C., \& West, T. (2001). The usefulness of economic value-added in the Australian context. Accounting Accountability and Performance, Vol. 7, No. 1, pp. 73-90.

Worthington, A. C., \& West T. (2004). Australian evidence concerning the information content of economic value-added. Australian Journal of Management, Vol. 29, No. 2, pp. 201-24. http://dx.doi.org/10.1177/031289620402900204

Zimmerman, J. L. (1997). EVA and Divisional Performance Measurement: Capturing Synergies and Other Issues. Journal of Applied Corporate Finance, Vol. 10, No. 2, pp. 98-109. http://dx.doi.org/10.1111/j.1745-6622.1997.tb00140.x

\section{Notes}

Note 1. www.cbi.ir

Table 1. Descriptive statistics

\begin{tabular}{|c|c|c|c|c|c|c|}
\hline Variables & Mean & Median & Maximum & Minimum & Std.Dev & LLC Test \\
\hline EVA $^{\circledR}$ & 0.598 & 0.082 & 41.90 & -13.57 & 2.992 & $-28.34^{*}$ \\
\hline REVA & 0.646 & 0.023 & 54.62 & -12.48 & 3.566 & $-3.665^{*}$ \\
\hline MVA & -0.327 & 0.387 & 546.69 & -140.17 & 22.09 & $-4.706^{*}$ \\
\hline SVA & 1.084 & 0.005 & 937.82 & -202.16 & 38.05 & $-9.033^{*}$ \\
\hline EPS & 4.95E-09 & 2.97E0-9 & $1.81 \mathrm{E}-07$ & $-1.00 \mathrm{E}-08$ & 9.79E-09 & $-7.006^{*}$ \\
\hline ROE & 0.567 & 0.452 & 11.23 & -1.120 & 0.647 & $-10.94^{*}$ \\
\hline ROA & 0.210 & 0.184 & 0.788 & -0.299 & 0.136 & $-12.41^{*}$ \\
\hline CFO & 1.252 & 0.185 & 122.01 & -7.689 & 6.857 & $-2.589^{*}$ \\
\hline ROS & 0.247 & 0.215 & 1.953 & -0.752 & 0.218 & $-16.39^{*}$ \\
\hline R (\%) & 34.54 & 12.18 & 820.16 & -79.52 & 86.28 & $-25.10^{*}$ \\
\hline \multicolumn{7}{|c|}{$\begin{array}{l}\text { Note: * significance at } 1 \text { percent level. EVA }{ }^{\circledR} \text { is economic value added, REVA is refined economic value added, MVA is marke } \\
\text { value added, SVA is shareholder value added. EPS is earning per share, ROE is return on equity, ROA is return on assets, CFO is cas } \\
\text { flow from operation, ROS is return on sales. R stands for stock return. The stationary of all variables has tested using Levin-Lin an } \\
\text { Chu (LLC) tests which according to the results all of them are corrected for stationary. }\end{array}$} \\
\hline
\end{tabular}


Table 2. Results of relative information content tests of measures

\begin{tabular}{|c|c|c|c|c|c|c|c|c|}
\hline \multirow[t]{2}{*}{ Measures } & \multicolumn{2}{|c|}{ Pooled Model } & \multicolumn{2}{|c|}{ Fixed Effect Model } & \multicolumn{2}{|c|}{ Random Effect Model } & \multirow{2}{*}{$\begin{array}{c}\text { F-Test } \\
\text { Statistic }\end{array}$} & \multirow{2}{*}{$\begin{array}{r}\text { Haus-Test } \\
\text { Statistic }\end{array}$} \\
\hline & $\mathrm{R}^{2}(\%)$ & F- Stat. & $\mathrm{R}^{2}(\%)$ & F- Stat. & $\mathrm{R}^{2}(\%)$ & F- Stat. & & \\
\hline EVA $^{\circledR}$ & 1.35 & $2.74^{*}$ & 0.03 & 0.743 & 0.08 & 0.931 & 0.742 & $11.038^{* * *}$ \\
\hline REVA & 3.70 & $5.083^{* *}$ & 1.10 & 0.805 & 0.32 & 2.316 & 0.792 & $15.976^{* * *}$ \\
\hline MVA & 1.03 & $0.215^{*}$ & 0.07 & 0.679 & 0.04 & 0.344 & 0.682 & $3.899^{* *}$ \\
\hline SVA & 1.22 & 1.574 & 0.04 & 0.664 & 0.09 & 0.698 & 0.664 & 0.230 \\
\hline EPS & 7.26 & $40.038^{* * *}$ & 2.133 & 0.813 & 3.02 & $22.417^{* * *}$ & 0.635 & 0.1232 \\
\hline ROA & 24.89 & $238.66^{* * *}$ & 19.54 & $1.273^{* *}$ & 7.08 & $34.916^{* * *}$ & 0.816 & $16.50^{* * *}$ \\
\hline ROE & 14.15 & $118.682^{* * *}$ & 16.20 & 1.018 & 5.96 & $45.67^{* * *}$ & 0.649 & 1.003 \\
\hline CFO & 2.46 & 1.777 & 0.00 & 0.714 & 0.11 & 0.789 & 0.714 & $7.944^{* * *}$ \\
\hline ROS & 5.40 & $41.104^{* * *}$ & 0.00 & 0.802 & 1.68 & $12.35^{* * *}$ & 0.704 & $4.829^{* *}$ \\
\hline
\end{tabular}

Note: ${ }^{*}$ significant at $0.10 ;{ }^{* *}$ significant at $0.05 ;{ }^{* * *}$ significant at 0.01 . The pooled models are tested and corrected for heteroskedasticity using Levene and Brown-Forsythe tests. According to F-test results, pooled models are more suitable than fixed and random effect models.

Table 3. Incremental information content of EVA ${ }^{\circledR}$

\begin{tabular}{|c|c|c|c|c|c|c|c|c|}
\hline \multirow{2}{*}{ Models } & \multicolumn{2}{|c|}{ Pooled Model } & \multicolumn{2}{|c|}{ Fixed Effect Model } & \multicolumn{2}{|c|}{ Random Effect Model } & \multirow{2}{*}{$\frac{\text { F-Test }}{\text { Statistic }}$} & \multirow{2}{*}{$\begin{array}{l}\text { Haus-Test } \\
\text { Statistic }\end{array}$} \\
\hline & $\mathrm{R}^{2}(\%)$ & F- Stat. & $\mathrm{R}^{2}(\%)$ & F- Stat. & $\mathrm{R}^{2}(\%)$ & F- Stat. & & \\
\hline Model 1 & 7.895 & $22.52^{* * *}$ & 1.20 & 0.92 & 3.27 & $12.171^{* * *}$ & 0.737 & $13.11^{* * *}$ \\
\hline Model 2 & 26.61 & $130.36^{* * *}$ & 6.08 & $1.40^{* * *}$ & 7.45 & $30.00^{* * *}$ & 0.908 & $26.92^{* * *}$ \\
\hline Model 3 & 14.92 & $63.02^{* * *}$ & 1.44 & 1.091 & 6.18 & $23.69^{* * *}$ & 0.713 & $9.123^{* *}$ \\
\hline Model 4 & 6.61 & $25.43^{* * *}$ & 0.00 & 0.903 & 1.17 & $7.250^{* * *}$ & 0.796 & $6.39^{* * *}$ \\
\hline Model 5 & 0.37 & 1.34 & 0.00 & 0.743 & 0.00 & 0.503 & 0.748 & $11.79^{* * *}$ \\
\hline
\end{tabular}

Table 4. Incremental information content of REVA

\begin{tabular}{|c|c|c|c|c|c|c|c|c|}
\hline \multirow{2}{*}{ Models } & \multicolumn{2}{|c|}{ Pooled Model } & \multicolumn{2}{|c|}{ Fixed Effect Model } & \multicolumn{2}{|c|}{ Random Effect Model } & \multirow{2}{*}{$\begin{array}{l}\text { F-Test } \\
\text { Statistic }\end{array}$} & \multirow{2}{*}{$\begin{array}{l}\text { Haus-Test } \\
\text { Statistic }\end{array}$} \\
\hline & $\mathrm{R}^{2}(\%)$ & F- Stat. & $\mathrm{R}^{2}(\%)$ & F- Stat. & $\mathrm{R}^{2}(\%)$ & F- Stat. & & \\
\hline Model 6 & 8.34 & $24.349^{* * *}$ & 3.05 & 0.9943 & 3.47 & $12.95^{* * *}$ & 0.792 & $18.92^{* * *}$ \\
\hline Model 7 & 32.42 & $164.757^{* * *}$ & 21.86 & $1.459^{* * *}$ & 7.82 & $30.50^{* * *}$ & 0.953 & $31.79^{* * *}$ \\
\hline Model 8 & 16.12 & $64.044^{* * *}$ & 2.18 & 1.1390 & 6.05 & $24.23^{* * *}$ & 0.751 & $13.16^{* * *}$ \\
\hline Model 9 & 6.89 & $26.625^{* * *}$ & 0.00 & 0.9662 & 1.89 & $7.96^{* * *}$ & 0.847 & $21.62^{* * *}$ \\
\hline Model 10 & 1.77 & $2.7817^{* *}$ & 0.00 & 0.7974 & 0.365 & 1.3152 & 0.789 & $15.75^{* * *}$ \\
\hline \multicolumn{9}{|c|}{$\begin{array}{l}\text { Note: }{ }^{* *} \text { significant at } 0.05 ;{ }^{* * *} \text { significant at } 0.01 \text {. The pooled models are tested and corrected for heteroskedasticity using } \\
\text { Levene and Brown-Forsythe tests. According to F-test results, pooled models are more suitable than fixed and random effect } \\
\text { models. }\end{array}$} \\
\hline
\end{tabular}

Table 5. Incremental information content of MVA

\begin{tabular}{|c|c|c|c|c|c|c|c|c|}
\hline \multirow{2}{*}{ Models } & \multicolumn{2}{|c|}{ Pooled Model } & \multicolumn{2}{|c|}{ Fixed Effect Model } & \multicolumn{2}{|c|}{ Random Effect Model } & \multirow{2}{*}{$\begin{array}{c}\text { F-Test } \\
\text { Statistic } \\
\end{array}$} & \multirow{2}{*}{$\begin{array}{c}\text { Haus-Test } \\
\text { Statistic }\end{array}$} \\
\hline & $\mathrm{R}^{2}(\%)$ & F- Stat. & $\mathrm{R}^{2}(\%)$ & F- Stat. & $\mathrm{R}^{2}(\%)$ & F- Stat. & & \\
\hline Model 11 & 7.29 & $20.119^{* * *}$ & 2.80 & 0.831 & 3.08 & $11.44^{* * *}$ & 0.655 & 3.908 \\
\hline Model 12 & 25.16 & $120.89^{* * *}$ & 4.306 & $1.279^{* *}$ & 7.16 & $27.74^{* * *}$ & 0.829 & $19.16^{* * *}$ \\
\hline Model 13 & 14.08 & $58.916^{* * *}$ & 0.313 & 1.019 & 5.97 & $22.86^{* * *}$ & 0.658 & 3.50 \\
\hline Model 14 & 5.39 & $20.502^{* * *}$ & 0.00 & 0.813 & 1.74 & $6.372^{* * *}$ & 0.718 & $8.024^{* *}$ \\
\hline Model 15 & 0.25 & 0.906 & 0.00 & 0.715 & 0.122 & 0.439 & 0.720 & $9.103^{* *}$ \\
\hline \multicolumn{9}{|c|}{$\begin{array}{l}\text { Note: }{ }^{* *} \text { significant at } 0.05 ; * * * \text { significant at } 0.01 \text {. The pooled models are tested and corrected for heteroskedasticity using } \\
\text { Levene and Brown-Forsythe tests. According to F-test results, pooled models are more suitable than fixed and random effect } \\
\text { models. }\end{array}$} \\
\hline
\end{tabular}


Table 6. Incremental information content of SVA

\begin{tabular}{|c|c|c|c|c|c|c|c|c|}
\hline \multirow{2}{*}{ Models } & \multicolumn{2}{|c|}{ Pooled Model } & \multicolumn{2}{|c|}{ Fixed Effect Model } & \multicolumn{2}{|c|}{ Random Effect Model } & \multirow{2}{*}{$\begin{array}{c}\text { F-Test } \\
\text { Statistic }\end{array}$} & \multirow{2}{*}{$\begin{array}{c}\text { Haus-Test } \\
\text { Statistic }\end{array}$} \\
\hline & $\mathrm{R}^{2}(\%)$ & F- Stat. & $\mathrm{R}^{2}(\%)$ & F- Stat. & $\mathrm{R}^{2}(\%)$ & F- Stat. & & \\
\hline Model 16 & 7.41 & $20.60 * * *$ & 3.01 & 0.813 & 3.09 & $11.49^{* * *}$ & 0.637 & 0.594 \\
\hline Model 17 & 24.78 & $118.44 * * *$ & 4.02 & $1.260^{* *}$ & 7.08 & $27.41^{* * *}$ & 0.815 & $17.07^{* * *}$ \\
\hline Model 18 & 14.25 & $59.784 * * *$ & 0.263 & 1.016 & 6.02 & $23.03^{* * *}$ & 0.652 & 1.60 \\
\hline Model 19 & 5.44 & $20.69 * * *$ & 0.00 & 0.797 & 1.72 & $6.29^{* * *}$ & 0.706 & $5.412^{*}$ \\
\hline Model 20 & 0.531 & 1.921 & 0.00 & 0.714 & 0.21 & 0.762 & 0.713 & $8.247^{* * *}$ \\
\hline \multicolumn{9}{|c|}{$\begin{array}{l}\text { Note: }{ }^{*} \text { significant at } 0.10 ;{ }^{* *} \text { significant at } 0.05 ;{ }^{* * *} \text { significant at } 0.01 . \text { The pooled models are tested and corrected for } \\
\text { heteroskedasticity using Levene and Brown-Forsythe tests. According to F-test results, pooled models are more suitable than } \\
\text { fixed and random effect models. }\end{array}$} \\
\hline
\end{tabular}

